\title{
METODE PENDIDIKAN ISLAM MENURUT AHMAD TAFSIR
}

\author{
MOH. WARDI \\ (Dosen STAI NATA Sampang) \\ Email: wardi_84@yahoo.co.id.
}

\begin{abstract}
Islamic education method is the way used to achieve the objectives of Islamic education. According to Ahmad Tafsir view, Islamic education methods that are relevant and effective in Islamic education are drakronis method, synchronousanalytical method, problem solving method, empirical method, deductive and inductive methods.

Drakronis is a teaching method that has prominent in history aspect. Synchronous-analytical method is a Islamic education method that provides theoretical analysis capabilities that are very useful for the development of mental faith and intellectual. Problem solving method is a method with approach of the students' study to find a variety of problems by finding the solution. Empirical method is a method of teaching that allows students to study Islam through the realization and internalization of norms and principles of Islam through an application process which leads to a social interaction. Inductive method conducted by educators by doing a special material to the general conclusion. While Deductive method conducted by educators in the teaching of Islam by showing the general rules and then break them with a variety of examples of problems that become unraveled.
\end{abstract}

\begin{abstract}
Abstrak
Metode pendidikan Islam adalah semua cara yang digunakan dalam upaya pencapaian tujuan pendidikan Islam. Menurut Ahmad Tafsir metode pendidikan Islam yang relevan dan efektif dalam pengajaran Islam diantaranya metode drakronis, metode sinkronis-analitis, metode problem solving, metode empiris, metode deduktif, dan metode induktif.

Drakronis adalah metode mengajar ajaran yang menonjol aspek sejarah. Metode Sinkronis-analitis merupakan suatu metode pendidikan Islam yang memberikan kemampuan analisis teoritis yang sangat berguna bagi perkembangan keimanan dan mental intelek. Metode Problem Solving adalah metode dengan pendekatan penelitian peserta didik untuk menemukan berbagai masalah dengan menemukan solusinya. Metode Empiris adalah suatu metode mengajar yang memungkinkan peserta didik mempelajari ajaran Islam melalui realisasi serta internalisasi norma dan kaidah Islam melalui proses aplikasi yang menimbulkan suatu interaksi sosial. Metode Induktif dilakukan oleh
\end{abstract}


pendidik dengan cara mengerjakan materi yang khusus menuju kesimpulan yang umum. Sedangkan Metode Deduktif dilakukan oleh guru dalam pengajaran Islam melalui cara menampilkan kaidah yang umum kemudian menjabarkannya dengan berbagai contoh masalah sehingga menjadi terurai.

Kata Kunci: Metode, Pendidikan Islam

\section{Pendahuluan}

Manusia adalah makhluk yang mungkin dapat dan harus dididik sesuai dengan hakikatnya sebagai makhluk ciptaan Allah SWT yang hidup sebagai satu diri (individu) dalam kebersamaan (sosialitas) di dalam masyarakat, karena memiliki kemungkinan tumbuh dan berkembang di dalam keterbatasan diri manusia. Pendidikan menjadi keharusan bagi manusia, karena manusia hanya akan menjadi manusia karena pendidikan. Mendidik berarti memanusiakan manusia untuk menjadi manusia yang seutuhnya (beriman), diperlukan pendidikan seperti yang diungkapkan oleh Prof Dr. Ahmad Tafsir, bahwa pendidikan harus mampu mendidik manusia menjadi manusia. Tujuan pendidikan ialah meningkatkan derajat manusia yang tinggi, itu yang dapat disebut manusia. ${ }^{1}$ Karena sasaran pendidikan adalah manusia. Pendidikan tersebut mencakup unsur Jasmani, Rohani dan Kalbu. Perpaduan tiga unsur itu dalam desain pendidikan akan menghasilkan sumber daya manusia yang baik dengan nilai kemanusian yang tinggi.

Sejak lahir manusia menghendaki kemajuan dalam kehidupannya. Sejak itulah timbul gagasan untuk mengalihkan, dan pengembangan kebudayaan melalui pendidikan. Oleh karena itu, dalam sejarah pertumbuhan masyarakat, pendidikan senantiasa menjadi perhatian utama dalam rangka kemajuan kehidupan generasi sejalan dengan tuntunan masyarakat. ${ }^{2}$

Pendidikan sebagai upaya untuk membangun sumber daya manusia memerlukan wawasan yang sangat luas, karena pendidikan menyangkut seluruh aspek kehidupan manusia, baik dalam pemikiran maupun pengalamannya. Oleh karena itu, pembahasan pendidikan tidak cukup berdasarkan pengalaman saja, melainkan dibutuhkan suatu pemikiran yang luas dan mendalam. Secara historis pertumbuhan dan perkembangan pendidikan Islam berperan sebagai mediator dimana ajaran Islam dapat disosialisasikan kepada masyarakat. Melalui pendidikan inilah masyarakat Indonesia dapat memahami, menghayati dan mengamalkan ajaran Islam sesuai dengan Al-Qur'an dan Al-Sunnah. Tetapi ada satu hal penting yang saya prihatinkan tentang pendidikan Islam di Indonesia. Menurut Ahmad Tafsir, mengapa setiap pendidikan Islam yang ada di bawah naungan lembaga atau sekolah-sekolah yang berbasis Islam secara pukul rata mutunya lebih rendah ketimbang lembaga atau sekolah pemerintah dan sekolah

\footnotetext{
${ }_{1}^{1}$ Ahmad Tafsir, Filsafat Pendidikan Islam, (Bandung: Remaja Rosdakarya, 2009 ), 46.

2 M. Arifin, Ilmu Pendidikan Tinjauan Teoritis dan Praktis Berdasarkan Pendekatan Interdisipliner, (Jakarta: Bumi Aksara. 2009), 1.
} 
yang dikelola oleh lembaga Katolik. ${ }^{3}$ Masalah yang paling besar adalah pendidikan kita belum bisa menghasilkan lulusan yang berakhlak mulia, tidak punya kepekaan sosial, suka narkoba dan suka korupsi, padahal itu semua termasuk koruptor adalah orang yang gagal menjadi manusia sekalipun dia seseorang pejabat atau pengusaha sukses.

Adapun yang harus dibenahi itu menurut Ahmad Tafsir ialah: (1) Hendaknya mendahulukan yang wajib dan membelakangkan yang sunnah. (2) Lebih memperhatikan mutu pendidikan sekolah Islam, karena mutu sekolah itu menentukan mutu umat Islam dan Negara Indonesia. (3) Etos ekonomi hendaknya diubah, keuntungan jangan seluruhnya diberikan kepada orang lain, umat Islam masih membutuhkan pendidikan. ${ }^{4}$

Akan tetapi, masih banyak permasalahan pendidikan Islam yang belum tuntas penyebabnya. Justru yang paling menentukan, yaitu pengelola sekolah, kepala sekolah dan guru sekolah, karena pendidikan Islam belum memiliki teoriteori pendidikan Modern dan Islam.

Menurut Ahmad Tafsir, ada dua teori pendidikan, yaitu teori pendidikan barat (ini disebut modern) dan teori pendidikan Islam yang berlandaskan AlQur' an dan Al-Hadist. ${ }^{5}$ Karena teori yang dikemukakan oleh Ahmad Tafsir tidak bermaksud berlaku secara universal sebagaimana layaknya suatu teori Ilmiah. Teori-teori yang dijelaskan oleh Ahmad Tafsir adalah khusus untuk pendidikanpendidikan Islam lebih unggul dan lebih baik mutunya dibandingkan pendidikan umum. Contoh-contoh permasalahan sebagaimana tersebut di atas itulah yang menjadi kajian penelitian ini, di tengah dekadensi moral bangsa yang berpangkal pada krisis pendidikan Islam harus ditingkatkan visi dan misinya agar tujuannya bisa tercapai dan berhasil dengan baik. Apabila menggunakan konsep-konsep pendidikan Islam yang sesuai dengan Al-Qur'an dan Al-Hadist. Oleh karena itu, penting kiranya penelitian ini dilakukan guna mencari konsep pendidikan Islam dengan mengambil pemikiran salah satu tokoh Islam yang banyak memberi kontribusi pemikirannya dalam dunia pendidikan Islam.

\section{Riwayat Hidup dan Pendidikan Ahmad Tafsir}

Ahmad Tafsir lahir di Bengkulu 19 April 1942. Pendidikannya diawali di Sekolah Rakyat (SR, sekarang SD) di Bengkulu. Setelah tamat di SR Ahmad Tafsir melanjutkan sekolah di PGA (Pendidikan Guru Agama) selama enam tahun di Yogyakarta. Selanjutnya belajar di Fakultas Tarbiyah IAIN Yogyakarta dan menyelesaikan jurusan Pendidikan Umum pada tahun 1969. Sejak tahun 1970 mengajar di Fakultas Tarbiyah IAIN Gunung Djati Bandung sampai sekarang. ${ }^{6}$

${ }^{3}$ Ahmad Tafsir, Ilmu Pendidikan dalam Persepektif Islam, (Bandung: Remaja Rosdakarya, 2007), 1.

${ }^{4}$ Ahmad Tafsir, Ilmu Pendidikan dalam Persepektif Islam, (Bandung: Remaja Rosdakarya, 2007), 3.

${ }_{5}^{5}$ Ahmad Tafsir, Ilmu Pendidikan dalam Persepektif Islam, (Bandung: Remaja Rosdakarya, 2007), 7.

${ }^{6}$ Ahmad Tafsir, Filsafat Pendidikan Islami, (Bandung: Remaja Rosdakarya, 2008 ), 343. 
Pada tahun 1975-1976 Ahmad Tafsir mendapat kesempatan mengikuti kursus intensif filsafat dan sejarah di IAIN Yogyakarta selama sembilan bulan. Dan pada tahun 1982-1987 Ahmad Tafsir mengikuti pendidikan lanjutan pada Sekolah Pasca Sarjana di IAIN Jakarta untk program S-2 dan S-3. Tahun 1984 Ahmad Tafsir mengadakan penelitian tentang sekolah-sekolah Muhammadiyah di beberapa kota. Hasil penelitiannya itu sebagian ditulis dalam tesis magisternya. Pada tahun 1987, Ahmad Tafsir harus menulis disertasi untuk mengakhiri studinya di sekolah Pasca serjana IAIN Jakarta.

Sebagai penganut Islam, sebenarnya Ahmad Tafsir sakit hati melihat kenyataan itu, mengapa orang katolik dapat membuat sekolah yang rata-rata baik, sedangkan Muhammadiyah (Islam), tidak? Sebagai peneliti, disini Ahmad Tafsir memang memihak, beliau terlibat dalam emosi keagamaannya. Akan tetapi, sakit hati itu tidak menyelesaikan persoalan. Lantas Ahmad Tafsir mencoba memperhatikan (penelitian dangkal) sekolah-sekolah yang dikelola oleh organisasi atau yayasan Islam selain Muhammadiyah. Ternyata hasilnya sama, bahkan cenderung lebih rendah mutunya ketimbang sekolah-sekolah Muhammadiyah. Ini sih, pukul rata menurut Ahmad Tafsir. Karena ada juga satudua sekolah Islam baik, bahkan favorit, bergengsi ukuran Ahmad Tafsir yang digunakan dalam membandingkan itu sederhana saja, yaitu jumlah lulusan yang diterima diperguruan tinggi negeri. Inilah permulaannya beliau tertarik serius untuk memperhatikan sekolah-sekolah Islam. Untuk menulis disertasi itu supaya memperdalam studinya tentang sekolah-sekolah Muhammadiyah. Menurut Ahmad Tafsir disertasi itu sendiri tidak terlalu baik, tetapi ada satu hal penting yang ditemukan oleh Ahmad Tafsir dalam penelitian itu: mengapa sekolahsekolah Islam secara pukul rata mutunya lebih rendah ketimbang sekolah-sekolah pemerintah dan sekolah yang dikelola oleh lembaga-lembaga Katolik.

Ketertarikan lahir dalam bentuk renungan dan penelitian lapangan dalam berbagai kesempatan. Tatkala Ahmad Tafsir diundang ke Ujung Pandang untuk satu seminar, Ahmad Tafsir memanfaatkan juga peluang itu untuk bertanya-tanya kepada kawan-kawannya dari sudut tanah air. Ahmad Tafsir tidak lupa bertanya kepada mereka tentang sekolah-sekolah Islam di tempat mereka. Yang diperoleh Ahmad Tafsir memperkuat pendapatnya bahwa sekolah-sekolah Islam memang pukul rata rendah mutunya. Kebetulan Ahmad Tafsir pernah memimpin SMP Muhammdiyah selama tujuh tahun di Bandung.

Selama di Yogyakarta Ahmad Tafsir tidak pernah lepas dari sekolah Muhammadiyah, belajar dan mengajar. Dari penelitian yang cukup mendalam, Ahmad Tafsir menemukan jawabannya bahwa sekolah-sekolah Islam bukan kekurangan dana atau umat Islam miskin, melainkan yang harus dibenahi ialah pola pemikirannya. ${ }^{7}$ Karena menurut Ahmad Tafsir umat Islam tidak sadar pentingnya pendidikan atau tidak memperhatikan mutu sekolah Islam.

Pada Tahun 1997, Ahmad Tafsir diangkat menjadi Guru Besar Ilmu Pendidikan di Fakultas IAIN Bandung. Tahun 1993 Ahmad Tafsir mempelopori

7 Ahmad Tafsir, Ilmu Pendidikan dalam Persepektif Islam, (Bandung: Remaja Rosdakarya, 2007), 1 . 
berdirinya Asosiasi Sarjana Pendidikan Islam (ASPI) dan sampai tahun 2000 masih menjabat sebagai ketua. Tidak lama setelah didirikan ASPI, sejak itu pula tahun 1994 sampai than 1996 banyak sekali mengadakan seminar nasional untuk membicarakan dan membahas Ilmu Pendidikan Islam. Hasilnya, tahun 1995 diterbitkan Epistemologi untuk Ilmu Pendidikan Islam, buku ini berisi tentang filsafat, paradigma, metodologi, model penelitian, dan peta penelitian semuanya untuk pendidikan Islam. ${ }^{8}$

Pada tahun 1974 Ahmad Tafsir mencoba menyusun diktat yang berisi tuntunan Lesson Plan (persiapan mengajar) khusus membantu mahasiswanya yang keluar menjadi guru agama Islam di sekolah menengah. Di dalam diktat itu baru dibuat pembahasan yang sangat singkat.

Secara berangsur-angsur diktat itu disempurnakan pada tahun 1986, penyempurnaan itu Ahmad Tafsir menganggap selesai dan siap diterbitkan pada tahun 1990. Naskah itu diterbitkan pertama kalinya (cetakan pertama) oleh Penerbit Remaja Rosdakaraya Bandung dengan judul buku Metodik Khusus Pendidikan Agam Islam (MKPAI). Pada tahun 1998 berlaku kurikulum baru Fakultas Tarbiyah yang disebut kurikulum 1988. Pada kurikulum 1988 itu nama mata kuliah Metodik Khusus Pendidikan Agama Islam (MKPAI) diganti dengan Metodologi Pengajaran Agama Islam (MPAI). Kemudian pada tahun 1994 kurikulum Tarbiyah berganti lagi. Dalam kurikulum itu digunakan Metodologi Pengajaran Agama Islam (MPAI) juga.

Pada tahun 1995, tatkala Ahmad Tafsir hendak menerbitkan cetakan ketiga buku MKPAI itu, judul MKPAI tersebut oleh Ahmad Tafsir diubah menjadi MPAI (Metodologi Pengajaran Agama Islam) disesuaikan dengan nama mata kuliah itu dalam kurikulum Fakultas Tarbiyah yang terbaru. Isi MPAI lebih luas dari pada isi MKPAI yang lama. Karena ada sedikit perubahan dan tambahan, ada 3 bab yaitu BAB 7 sampai dengan BAB 9 sebanyak 45 halaman dan beberapa revisi pada halaman-halaman yang lain. ${ }^{9}$

Sejak lama Ahmad Tafsir mengajarkan Filsafat Pendidikan dan Filsafat Pendidikan Islami di beberapa perguruan tinggi, pada jenjang S1 maupun S2. Sebelum Ahmad Tafsir memberikan kuliah biasanya beliau telah menyiapkan bahan, yang kadang-kadang telah berupa makalah. Makalah beliau dibagikan kepada mahasiswa lantas beliau membahasnya. Seringkali terjadi perubahan dan perbaikan pada isi makalah setelah pembahasan itu.

Makalah-makalah Ahmad Tafsir itu diseleksi secara ketat kemudian diambil oleh temannya kemudian ditulis ulang. Dengan ditulis ulang kesempatan yang baik untuk memperbaiki dan memperkaya data dengan menambahkan makalahmakalah seminar, dan lain-lain,sehingga jadilah buku Filsafat Pendidikan Islam.

Ahmad Tafsir berterima kasih kepada para mahasiswanya yang telah ikut mematangkan gagasan-gagasannya. Jadi buku Filsafat Pendidikan Islam ini yang amat sederhana menjadi media beliau, mengajak para pembaca untuk

\footnotetext{
8 Ahmad Tafsir, Filsafat Pendidikan Islami, (Bandung: Remaja Rosdakarya, 2008), 313.

9 Ahmad Tafsir, Metodologi Pengajaran Agana Islam, (Bandung: Remaja Rosdakarya, 2008 ), V.
} 
mendiskusikan gagasan-gagasan tersebut. Ahmad Tafsir berterima kasih karena mereka mendorong beliau menerbitkan buku ini, kata mereka agar dapat dibaca orang banyak. Ahmad Tafsir berterima kasih kepada banyak orang yang membantu, mendorong, yang akhirnya menjadi penyebab beliau berani menerbitkan buku ini. Secara khusus beliau berterima kasih kepada muridnya yang bernama Tedy Priatna dan Deden Efendi yang telah membantu beliau ketika buku Filsafat pendidikan Islami masih berupa draf, yang kadang-kadang mereka juga mengejek gagasan-gagasan yang beliau tulis dalam bukunya. Kalau mereka mengejek biasanya Ahmad Tafsir akan berkata, "diam dulu, kamu kan baru lahir kemarin." Dalam hal mengejek itu Darun Setiyadi juga sering ikut-ikutan. Tetapi dibalik itu semua ejekan mereka sebenarnya membantu Ahmad Tafsir "mematangkan" gagasan-gagasan beliau tersebut, karena topik pembahasan Filsafat Pendidikan Islam banyak yang sama dengan topik pembahasan Ilmu Pendidikan Islam, tetapi mahasiswa tidak perlu mengajukan pertanyaan itu. Inilah penyebab utama yang mendorong Ahmad Tafsir menulis buku Filsafat Pendidikan Islam dan Ilmu Pendidikan Islam. Ahmad Tafsir ingin menjelaskan perbedaan antara Filsafat Pendidikan Islam dan Ilmu Pendidikan Islam. Ahmad Tafsir mencoba memisahkan teori-teori Ilmu pendidikan Islam dari teori-teori Filsafat pendidikan Islam. ${ }^{10}$

\section{Karya Ahmad Tafsir}

Karya tulis (buku, artikel, dan makalah) pada umumnya dalam pendidikan dan filsafat, tetapi cukup sering menyajikan makalah dalam seminar-seminar nasional dan kemasyarakatan, pendidikan, agama, filsafat dan akhir-akhir ini sering menulis tentang tasawwuf. Ahmad Tafsir banyak menulis di surat kabar berupa artikel ringan dan umumnya mengenai Agama dan pendidikan, sekali-kali mengajukan pendekatan filsafat.11 Ahmad Tafsir aktif dalam penerbitan majalah terakreditasi nasional yakni Media Nasional.

Selain menulis buku Ahmad Tafsir juga banyak menulis di surat kabar, baik lokal Bandung maupun Nasional. Baik tulisan-tulisannya yang pernah dimuat di harian-harian itu. Oleh karena itu, banyak yang menyaksikan bahasa beliau kebanyakan menggunakan gaya surat kabar, tetapi menurut Ahmad Tafsir tidak apalah, yang penting dapat dipahami.

Beberapa karya ilmiah dan buku suntingannya diantaranya: yang pernah diterbitkan oleh beliau adalah: Filsafat Umum Akal dan Hati sejak Thales sampai Capra (2010), Ilmu Pendidikan Islam, Kajian Pendidikan Islam di IAIN Yogyakarta (mimbar study no 3 tahun XXIII, 1999), Pendidikan Agama dalam Keluarga (1996), Epistemologi untuk Ilmu Pendidikan Islam (1995), Metodologi Pengajaran Agama Islam (2008), Pendidikan Agama dalam Rumah Tangga (untuk umur 0-12 tahun), Pendidikan Agama dalam Rumah Tangga (untuk umur 13-18 tahun).

${ }^{10}$ Ahmad Tafsir, Filsafat Pendidikan Islami, (Bandung: Remaja Rosdakarya, 2008), iii.

${ }^{11}$ Ahmad Tafsir, Filsafat Pendidikan Islami, (Bandung: Remaja Rosdakarya, 2008) , 343. 
Mengenai ontology, epistemologi dan aksiologi pengetahuan dan pendidikan agama di lembaga kursus. Ada lagi karya beliau yang sangat terkenal dalam dunia pendidikan Islam, yaitu buku Metodik Khusus Pendidikan Islam (1992), dan Ilmu Pendidikan dalam Persepektif Islam (1992), buku yang pertama (Metodik Khusus Pendidikan Islam) secara rinci mengungkapkan beberapa hal penting dalam soal metodologi ini, termasuk tentang pembuatan perencanaan pengajaran (Lesson Plan), prinsip dan metode mengajar dan belajar, prinsip evaluasi, model-model dasar rencana pengajaran, model dasar metodik khusus pendidikan agama Islam, dan metode cara belajar siswa aktif (CBSA).

Sedangkan buku kedua (Ilmu Pendidikan dalam Persepektif Islam), ini mencakup pembahasan lebih luas tentang pola-pola kajian pendidikan Islam di Indonesia, seperti: tujuan pendidikan Islam, kurikulum pendidikan Islam, guru dalam pendidikan Islam, dan peralatan dalam pendidikan Islam, metode pendidikan Islam, pendidikan dalam keluarga dan pendidikan Islam alternatif, seperti pesantren.12 Dan buku Filsafat Pendidikan Islam di dalamnya menjelaskan tentang hakikat manusia, hakikat pendidikan, dasar pendidikan, tujuan pendidikan, kurikulum pendidikan, peserta didik, lembaga pendidikan, proses dan pengembangan pendidikan.

\section{Metode Pendidikan Islam Menurut Ahmad Tafsir}

Yang dimaksud dengan metode pendidikan Islam ialah semua cara yang digunakan dalam upaya mendidikan. Kata "metode" disini diartikan secara luas. Karena mengajar adalah salah satu bentuk upaya mendidik, maka metode yang dimaksud disini mencakup juga metode mengajar.

Dalam literatur ilmu pendidikan, khususnya ilmu pengajaran, dapat ditemukan banyak metode mengajar. Adapun metode mendidik, selain dengan cara mengajar, tidak terlalu banyak dibahas oleh para ahli. Sebabnya, mungkin metode mengajar lebih jelas, lebih tegas, objektif, bahkan universal. Sedangkan metode mendidik selain mengajar lebih subjektif, kurang jelas, kurang tegas, lebih bersifat seni dari pada sebagai sains.

Jadi, sebenarnya untuk kepentingan pengembangan teori-teori pendidikan Islam, masalah metode mengajar tidaklah terlalu sulit. Menurut Ahmad Tafsir, karena metode-metode mengajar yang dikembangkan di Barat dapat saja digunakan atau diambil untuk memperkaya teori tentang metode pendidikan Islam. ${ }^{13}$

Metodik umum atau metodologi pengajaran telah membicarakan berbagai kemungkinan metode mengajar yang dapat digunakan guru dalam menyelenggarakan kegiatan belajar mengajar. Telah disediakan metode ceramah, tanya jawab, diskusi, metode pemberian tugas dan resitasi, dan lain-lain. Guru

12 Azyumardi Azra, Pendidikan Islam Tradisi dan Modernisasi Menuju Melenium Baru, (Jakarta: Logos Wacana Ilmu, 2002), 93.

13 Ahmad Tafsir, Ilmu Pendidikan dalam Perspektif Islam, (Bandung: Remaja Rosdakarya, 2008), 6. 
dapat memilih metode yang paling tepat ia gunakan. Dalam pemilihan tersebut banyak yang harus dipertimbangkan, antara lain:

1. Keadaan murid yang mencakup pertimbangan tentang tingkat kecerdasan, kematangan, perbedaan individu lainnya.

2. Tujuan yang hendak dicapai, jika tujuannya pembinaan daerah kognitif maka metode Drill ${ }^{14}$ kurang tepat digunakan.

3. Situasi yang mencakup hal yang umum seperti situasi kelas, situasi lingkungan. Bila jumlah murid begitu besar, maka metode diskusi agak sulit digunakan, apalagi bila ruangan tersedia kecil. Metode ceramah harus dipertimbangkan antara lain jangkauan suara guru.

4. Alat-alat yang tersedia akan mempengaruhi pemilihan metode yang akan digunakan. Metode eksperimen harus tersedia, dipertimbangkan juga jumlah dan mutu alat itu.

5. Kemampauan mengajar telah menentukan, mencakup kemampuan fisik, keahlian. Metode ceramah memerlukan kekuatan guru secara fisik. Guru yang mudah payah, kurang kuat berceramah dalam waktu yang lama. Dalam hal seperti ini sebaiknya ia menggunakan metode lain yang tidak memerlukan tenaga yang banyak. Informasi yang diperlukan dalam metode diskusi kadang-kadang lebih banyak dari pada sekedar bahan yang diajarkan. ${ }^{15}$

Menurut Ahmad Tafsir metode internalisasi memberikan saran tentang cara mendidik murid agar beragama. Teknik-tenik metode ini masih merupakan daerah penuh tantangan, masih diperlukan daya kreatif tingkat tinggi untuk mengembangkan teknik-tekniknya. Metode internalisasi mempunyai tiga tujuan pembelajaran, metode ini berlaku untuk pembelajaran apa saja.

1. Tahu, mengetahui (knowing). Disini tugas guru ialah mengupayakan agar murid mengetahui sesuatu konsep.

2. Mampu melaksanakan atau mengerjakan yang ia ketahui (doing).

3. Murid menjadi yang ia ketahui itu. Konsep ini seharusnya tidak sekedar menjadi miliknya tetapi menjadi satu dengan kepribadiannya. ${ }^{16}$

Tatkala orang mendesain pendidikan, maka harus memulainya dengan merumuskan tujuan yang hendak dicapai. Berdasarkan dasar pendidikan yang menjadi pandangan hidup pendesain itu, ia harus merumuskan tujuan pendidikan. Jadi, tujuan pendidikan pada dasarnya ditentukan oleh pandangan hidup (way of life) orang mendesain pendidikan itu. ${ }^{17}$ Jika pandangan hidup

\footnotetext{
14 Metode Drill artinya dilatih secara membabi buta, diulang-ulang tanpa melalui proses berpikir, sampai akhirnya keterampilan tertentu dikuasai, artinya mampu dilakukan secara otomatis. Semakin sering berlatih seseorang akan semakin terampil. Metode ini biasanya digunakan untuk melatih keterampilan fisik. Lihat di Ahmad Tafsir, Metodologi Pengajaran Agama Islam, (Bandung: Remaja Rosdakarya, 2008), 101.

15 Ahmad Tafsir, Metodologi Pengajaran Agama Islam, (Bandung: Remaja Rosdakarya, 2008 ), 33.

${ }^{16}$ Ahmad Tafsir, Filsafat Pendidikan Islami, (Bandung: Remaja Rosdakarya, 2008 ), 223-224.

17 Ahmad Tafsir, Filsafat Pendidikan Islami, (Bandung: Remaja Rosdakarya, 2008 ), 75.
} 
(philosophy of life) adalah Islam, maka tujuan pendidikan menurut anda haruslah diambil dari ajaran Islam. ${ }^{18}$ Karena tujuan pendidikan adalah hal pertama dan terpenting bila kita merancang, membuat program, serta mengevaluasi pendidikan $100 \%$ ditentukan oleh rumusan tujuan. Sebab mudahnya mutu pendidikan akan segera terlihat pada rumusan tujuan pendidikan.

Untuk merumuskan tujuan pendidikan Islam harus diketahui lebih dahulu ciri manusia sempurna menurut Islam. Untuk mengetahui ciri manusia diketahui hakekat manusia menurut Islam. Apa hakekat manusia menurut Islam? Manusia adalah makhluk ciptaan Allah, ia tidak muncul dengan sendirinya atau berada oleh sendirinya. Karena manusia adalah makhluk yang perkembangannya dipengaruhi oleh pembawaan dan lingkungan.

Ciri manusia yang baik secara umum dapat dibagi menjadi tiga macam:

1. Badan sehat, kuat mempunyai keterampilan (aspek jasmani)

2. Pikiran cerdas serta pandai (aspek akal)

3. Hati berkembang dengan baik (rasa, kalbu, ruhani). ${ }^{19}$

Bentuk metode pendidikan Islam yang relevan dan efektif dalam pengajaran Islam adalah:

1. Metode Drakronis

Suatu metode mengajar ajaran yang menonjol aspek sejarah. Metode ini memungkinkan adanya study komperatif tentang berbagai penemuan dan pengembangan ilmu pengetahuan, sehingga peserta didik memiliki ilmu pengetahuan yang relevan. Metode ini menyebabkan peserta didik ingin mengetahui, memahami, menguraikan dan meneruskan ajaran Islam dari sumber-sumber dasar, yakni Al-Qur'an dan As-sunnah.

2. Metode Sinkronis-analitis

Suatu metode pendidikan Islam yang memberikan kemampuan analisis teoritis yang sangat berguna bagi perkembangan keimanan dan mental intelek. Metode ini semata-mata mengutamakan segi pelaksanaan atau implikasi praktis. Teknik pengajarannya meliputi diskusi, lokakarya, seminar, kerja kelompok resensi buku.

3. Metode Problem Solving

Metode ini merupakan penelitian peserta didik yang dihadapkan pada berbagai masalah suatu cabang ilmu pengetahuan dengan solusinya. Metode ini dapat dikembangkan melalui simulasi, micro-teaching dan critacal incident. Di dalam metode ini cara menegaskan keterampilan lebih dominan ketimbang pengembangan pikiran peserta didik (mental intelektualnya). Sehingga terdapat kelemahannya yakni terbatasnya perkembangan pikiran peserta didik mungkin hanya terbatas pada kerangka yang sudah tetap dan akhirnya bersifat mekanistik.

4. Metode Empiris

18 Ahmad Tafsir, Ilmu Pendidikan dalam Perspektif Islam, (Bandung: Remaja Rosdakarya, 2008), 46.

${ }^{19}$ Ahmad Tafsir, Metodologi Pengajaran Agama Islam, (Bandung: Remaja Rosdakarya, 2008), 14 . 
Suatu metode mengajar yang memungkinkan peserta didik mempelajari ajaran Islam melalui realisasi serta internalisasi norma dan kaidah Islam melalui proses aplikasi yang menimbulkan suatu interaksi sosial. Kemudian secara deskriptif, proses-proses interaksi dapat dirumuskan dalam suatu sistem norma baru. Keuntungan metode ini adalah peserta didik tidak hanya memiliki kemampuan secara teoritis-normatif, tetapi juga adanya pengembangan deskriptif inovasi beserta aplikasinya dalam kehidupan sosial.

5. Metode Induktif

Metode ini dilakukan oleh pendidik dengan cara mengerjakan materi yang khusus menuju kesimpulan yang umum. Tujuan metode ini adalah agar peserta didik bisa mengenal kebenaran-kebenaran dan hukum-hukum setelah melalui riset.

6. Metode Deduktif

Metode ini dilakukan oleh guru dalam pengajaran Islam melalui cara menampilkan kaidah yang umum kemudian menjabarkannya dengan berbagai contoh masalah sehingga menjadi terurai. Metode ini sangat diperlukan dalam pendidikan karena peserta didik bisa membandingkan dan merumuskan konsep-konsep. Hal ini menunjukkan bahwa pendidik dapat memainkan peranan dalam mengembangkan deduksi melalui pemberian fakta-fakta atau materi-materi yang diperlukan terhadap peserta didik dan memberikan kesempatan kepada mereka untuk menentukan prinsip umum tersebut. 


\section{DAFTAR PUSTAKA}

Arifin, M., 2009, Ilmu Pendidikan Tinjauan Teoritis dan Praktis Berdasarkan Pendekatan Interdisipliner, Jakarta: Bumi Aksara.

Azra, Azyumardi, 2002, Pendidikan Islam Tradisi dan Modernisasi Menuju Melenium Baru, Jakarta: Logos Wacana Ilmu.

Tafsir, Ahmad, 2007, Filsafat Pendidikan Islami, Bandung: Remaja Rosdakarya.

Tafsir, Ahmad, 2007, Ilmu Pendidikan dalam Persepektif Islam, Bandung: Remaja Rosdakarya.

Tafsir, Ahmad, 2008, Ilmu Pendidikan dalam Perspektif Islam, Bandung: Remaja Rosdakarya.

Tafsir, Ahmad, 2008, Metodologi Pengajaran Agama Islam, Bandung: Remaja Rosdakarya.

Tafsir, Ahmad, 2009, Filsafat Pendidikan Islam, Bandung: Remaja Rosdakarya. 